\title{
Molecular characterization of Malassezia sympodialis and Malassezia furfur from cattle with and without otitis
}

\author{
[Caracterização molecular de isolados de Malassezia sympodialis e Malassezia furfur provenientes de \\ bovinos com e sem otite externa]$$
\text { E.R. Duarte }{ }^{1} \text {, J.S. Hamdan }{ }^{2}
$$ \\ ${ }^{1}$ Instituto de Ciências Agrárias - UFMG \\ Av. Universitária, 1000 \\ 39400-006 - Montes Claros, MG \\ ${ }^{2}$ Instituto de Ciências Biológicas - UFMG - Belo Horizonte, MG
}

\begin{abstract}
A molecular study of Malassezia strains isolated from cattle with or without otitis was carried out by random amplified polymorphic DNA analysis (RAPD). DNA was extracted and purified from nine strains of Malassezia sympodialis and fourteen of Malassezia furfur. These microorganisms were collected from eight different bovine herds in Minas Gerais state, Brazil. The RAPD analysis and phenograms did not show the formation of genetically distinct groups among the strain isolated from cattle with or without otitis raised in the same herds. Genetic heterogeneity was observed among Malassezia strains from different geographic origins. These data suggest that genetically similar M. sympodialis and M. furfur strains found as members of the normal ear microbiota could become opportunistically active in the inflammatory process in cattle.
\end{abstract}

Keywords: bovine, otitis, Malassezia spp., RAPD

\section{RESUMO}

A caracterização molecular de amostras de Malassezia spp., isoladas de bovinos com e sem otite, foi realizada por meio da técnica do DNA polimórfico amplificado ao acaso (RAPD). DNAs de nove amostras de Malassezia sympodialis e quatorze de M. furfur foram extraidos e purificados. Essas amostras foram provenientes de oito diferentes rebanhos bovinos no estado de Minas Gerais, Brasil. A análise de RAPD e os fenogramas não revelaram a formação de grupos geneticamente distintos entre amostras isoladas de bovinos, criados no mesmo rebanho, com ou sem otite. Heterogeneidade genética foi observada entre amostras de diferentes origens geográficas. Os dados sugerem que isolados geneticamente semelhantes e membros da microbiota normal do ouvido podem participar, como oportunistas, no processo inflamatório do conduto auditivo externo de bovinos.

Palavras-chave: bovino, otite, Malassezia spp., RAPD

\section{INTRODUCTION}

In tropical regions, otitis in cattle is commonly attributed to parasitic infections caused by rhabditiform nematodes. These infections have a serious economic dimension, especially in Gyr cattle since the outcome can be fatal. Bovine otitis may also be caused by acarids of the genus Raillietia, which are frequently found in Nellore and Guzera cattle as well as in European breeds (Araújo et al., 1996; Duarte et al., 2001b).

Recebido em 15 de janeiro de 2008

Aceito em 27 de junho de 2008

E-mail: duartevet@hotmail.com
The genus Malassezia comprises yeasts of increasing importance in human and veterinary medicine (Leite et al., 2003; Gandra et al., 2006; Oliveira et al., 2006). Yeasts of the genus Malassezia have been studied in cattle and have been detected in significant frequencies, ranging from $16 \%$ to $33 \%$ in ear and skin samples from healthy cattle (Guillot et al., 1994; Duarte et al., 1999).

The possible role of yeasts of the genus Malassezia in the etiopathology of bovine 
parasitic otitis has been described. In a mycological study of bovine parasitic otitis, the genus Malassezia was the most prevalent. Malassezia sympodialis, Malassezia fufur, and Malassezia globosa were the species most frequently encountered species in prevalence studies of yeasts of this genus in the external ear of cattle with otitis (Duarte et al., 2001a; Duarte et al., 2003).

The random amplification of polymorphic DNA (RAPD) has been performed to monitor the spread of infections caused by Malassezia species in neonatal intensive care units. Belkum et al. (1994) observed homogeneity between the genomic profiles of clinical strains of the same species of $M$. furfur and Malassezia pachydermatis and heterogeneity between clinical and reference strains of the same species.

The genomic profiles of 13 clinical strains isolated from dogs with external otitis or seborrheic dermatitis and the reference sample M. pachydermatis (CBS 1879) were identical, showing 12 bands using the technique of RAPD (Aizawa et al., 1999).

The role that these yeasts play in the etiology of otitis is not clear. It is important to evaluate whether the strains from animals with otitis and those without otitis have similar or different genomic characteristics. Thus, this study had the objective to characterize the genetic profiles of strains of Malassezia simpodialis and M. furfur isolated from cattle with otitis and healthy cattle using the RAPD technique.

\section{MATERIALS AND METHODS}

The twenty two Malassezia strains isolated from cattle selected for the present study came from previous epidemiological studies (Duarte et al., 2003). These strains were collected from eight different bovine herds in Minas Gerais state, Brazil. The geographic origin and host characteristics of the strains used in this research are described in table 1.

Table 1. Clinical strains of Malassezia spp. from cattle raised in Minas Gerais State, Brazil, and standard $M$. furfur strain used in the RAPD analysis

\begin{tabular}{lll}
\hline Strains & Hosts & Origin (City/Region) \\
\hline Malassezia furfur & & \\
CBS 1878 & Human with pityriasis capitis & Delft/ Netherlands \\
VG C 12 & Gyr cow & Caeté/ Centre \\
VG C 227 & Gyr cow with otitis & Caeté/ Centre \\
VG C 303 & Gyr cow with otitis & Caeté/ Centre \\
VG C 390 & Gyr cow & Caeté/ Centre \\
NG C 06 & Gyr heifer & Caeté/Centre \\
VH Pm Paloma & Holstein cow with otitis & Pará de Minas/ Centre \\
VH Pm Londrina & Holstein cow & Pará de Minas/ Centre \\
VH Pm Duqueza & Holstein cow & Pará de Minas/ Centre \\
VG Luz 11 & Gyr cow & Luz / Centre \\
BM Luz 02 & Hybrid calf & Luz / Centre \\
VH L 224 & Holstein cow & Lavras/ South \\
BM L 01 & Hybrid calf & Lavras/ South \\
VG Rc 4349 & Gyr cow with otitis & Rio Casca/ East \\
Malassezia sympodialis & & \\
VM Pom Morena & Hybrid cow & Pompéu/ Centre \\
VM Pom Sortuda & Hybrid cow & Pompéu/ Centre \\
VG Ig 14 & Gyr cow & Igarapé/ Centre \\
VG Luz 348 & Gyr cow & Luz/ Centre \\
VG Luz 481 & Gyr cow & Luz/ Centre \\
VG Luz 475 & Gyr cow with otitis & Luz/ Centre \\
VG Luz 497 & Gyr cow with otitis & Luz/ Centre \\
VM Ub 23 & Hybrid cow & Uberaba/ West \\
VM Ub 26 & Hybrid cow & Uberaba/ West \\
\hline
\end{tabular}


The yeasts were identified using the following criteria: morphological characteristics; growth on Dixon medium at different temperatures $(32,37$, and $40^{\circ} \mathrm{C}$ ); growth on Sabouraud's medium supplemented with tween 20,40, 80, or cremophor EL, esculin and catalysis screening; and flurochromes and pigments synthesis (Guého et al., 1998, Mayser et al., 1998). The standard strain CBS-1878 (M. furfur) was simultaneously tested as control for the biochemicalphysiological tests and genetic analysis.

Following species identification, the isolated strains were seeded on solid Dixon medium and incubated for five days at $32^{\circ} \mathrm{C}$ to obtain microorganisms at the exponential growth phase. A loop full of cells from each strain was then collected and suspended in $500 \mu \mathrm{l}$ of sorbitol citrate buffer (sorbitol $1.1 \mathrm{M}$, sodium citrate $0.1 \mathrm{M}, \mathrm{pH} 5.6$ ). To the cell suspension, $1 \mathrm{ml}$ of extracting buffer [Tris-spermidine $-40 \mathrm{mM}$ tris$\mathrm{HCl}$ ( $\mathrm{pH} 8.0$ ), 4mM spermidine, 10mM EDTA, $0.1 \mathrm{M} \mathrm{NaCl}, 10 \mathrm{mM}$ of $\beta$-mercaptoetanol, and $0.1 \%$ sodium dodecyl sulfate] supplemented with $50 \mathrm{mg}$ of glucanase ${ }^{1}$ was added. Afterwards, the mixture was incubated at $37^{\circ} \mathrm{C}$ under agitation in a thermoshaker operated at $35 \mathrm{rpm}$ for $3 \mathrm{~h}$.

One phenol extraction step followed by two phenol/chloroform extractions steps were performed as described elsewhere. Following a centrifugation at $3^{\circ} \mathrm{C}$ at $14 \mathrm{~kg} \times 3 \mathrm{~min}$, the aqueous phase was transferred to a new microtube and the RNA was removed by treatment with $10 \mathrm{mg} / \mathrm{ml}$ RNAse for $30 \mathrm{~min}$ at $37^{\circ} \mathrm{C}$. After new phenol-chloroform extraction steps, the DNA was precipitated by addition of 2.5 volumes of ethanol in the presence of $0.3 \mathrm{M}$ $\mathrm{NaCl}$ followed by a $-20^{\circ} \mathrm{C}$ overnight storage and centrifugation at $3^{\circ} \mathrm{C}$ at $14 \mathrm{~kg} \times 5-10 \mathrm{~min}$. The pellet was washed with $70 \%$ ethanol, dried at room temperature, and suspended in $500 \mu$ of Tris EDTA pH 8.0 buffer (Sambrook et al., 1989). DNA quantification was performed by comparison with DNA standards electrophoresed in agarose gels. The following primers were used: M13 F, M13 R, M13 FR, OPA 1, OPA 2, SOY, $8 \mathrm{~L}$, and $10 \mathrm{~L}$ for RAPD reaction. The primers M13 F (5'-GAGGGTGGCGGTTCT-3'), OPA 2 (5'-TGCCGAGCTG-3'), and OPA 4 (5'AATCGGGCTG-3') presented the best results.

${ }^{1}$ Glucanex - Novo Nordisk Ferment Ltda. - Dittingen, Switzerland.
These oligonucleotides were selected based on high-intensity bands, hypervariability, and good definition of DNA fragments.

The RAPD reaction mixture contained 1 ng of genomic DNA, 1 picomol of the primer, $500 \mu \mathrm{M}$ of each dNTP, and $0.3 \mathrm{U}$ of Taq DNA polymerase $^{2}$ in a final volume of $10 \mu$ l of the PCR buffer (100mM Tris-HCl, pH 8.3, 500mM $\mathrm{KCl}, 3.5 \mathrm{mM} \mathrm{MgCl}_{2}$ ). The PCR reactions were conducted in a Perkin-Elmer GeneAmp PCR System 2400 according to the following parameters: denaturation at $95^{\circ} \mathrm{C}$ for $30 \mathrm{sec}$ followed by 40 cycles at $94^{\circ} \mathrm{C}$ for $1 \mathrm{~min}$, annealing at $40^{\circ} \mathrm{C}$ for $2 \mathrm{~min}$, and extension at $72^{\circ} \mathrm{C}$ for $2 \mathrm{~min}$. In the last cycle, the extension step time was increased to $7 \mathrm{~min}$. Reproducibility was checked by repeating PCR for at least three times. RAPD products were analyzed by electrophoresis on an $8 \%$ polyacrilamide gel in Tris borate-EDTA, $\mathrm{pH} 8.0$ buffer and visualized by silver staining as described by Santos et al. (1993).

For RAPD data analysis, the relative mobility position of all bands present in each of the Malassezia strain analyzed were calculated and transformed into a data matrix in which the character one means the presence of a specific band and zero represents its absence. Nei and Li algorithm contained in the TREECON computer package program was used to calculate the genetic distances between the strains. The phenograms were then constructed by UPGMA (Unweighted Pair Group with Arithmetic Mean) method and the robustness of the tree topology was assessed resampling 1000 times by bootstrap (Van de Peer and Wachter, 1994). The isolated strains were considered similar genetic types varying up to two DNA bands of electrophoresis on polyacrilamide gel.

\section{RESULTS AND DISCUSSION}

The primers M13 F, OPA 2, and OPA 4 produced more polymorphic and reproductive profiles. These oligonucleotides were selected based on high-intensity bands, hypervariability, and good definition of DNA fragments. The primer OPA 2 permitted the observation of the most intra-specific variation between the genomic profiles obtained for the analyzed

\footnotetext{
${ }^{2}$ Taq DNA polymerase- Gibco BRL - Gaythersburg, USA.
} 
strains of $M$. sympodialis and M13 F primer to M. furfur strains.

Figure 1 shows the electrophoretic profiles on $8 \%$ polyacrilamide gel and the phenogram, constructed by UPGMA, of $M$. sympodialis from cattle with or without otitis generated by RAPD-
PCR with OPA 2 primer. Two genetic types can be observed and the strains VM Pom Morena and VM Pom Sortuda from the same bovine herd in same region exhibited identical RAPD patterns. The other strains were clustered in a single group (a) with strains from animal with or without otitis.
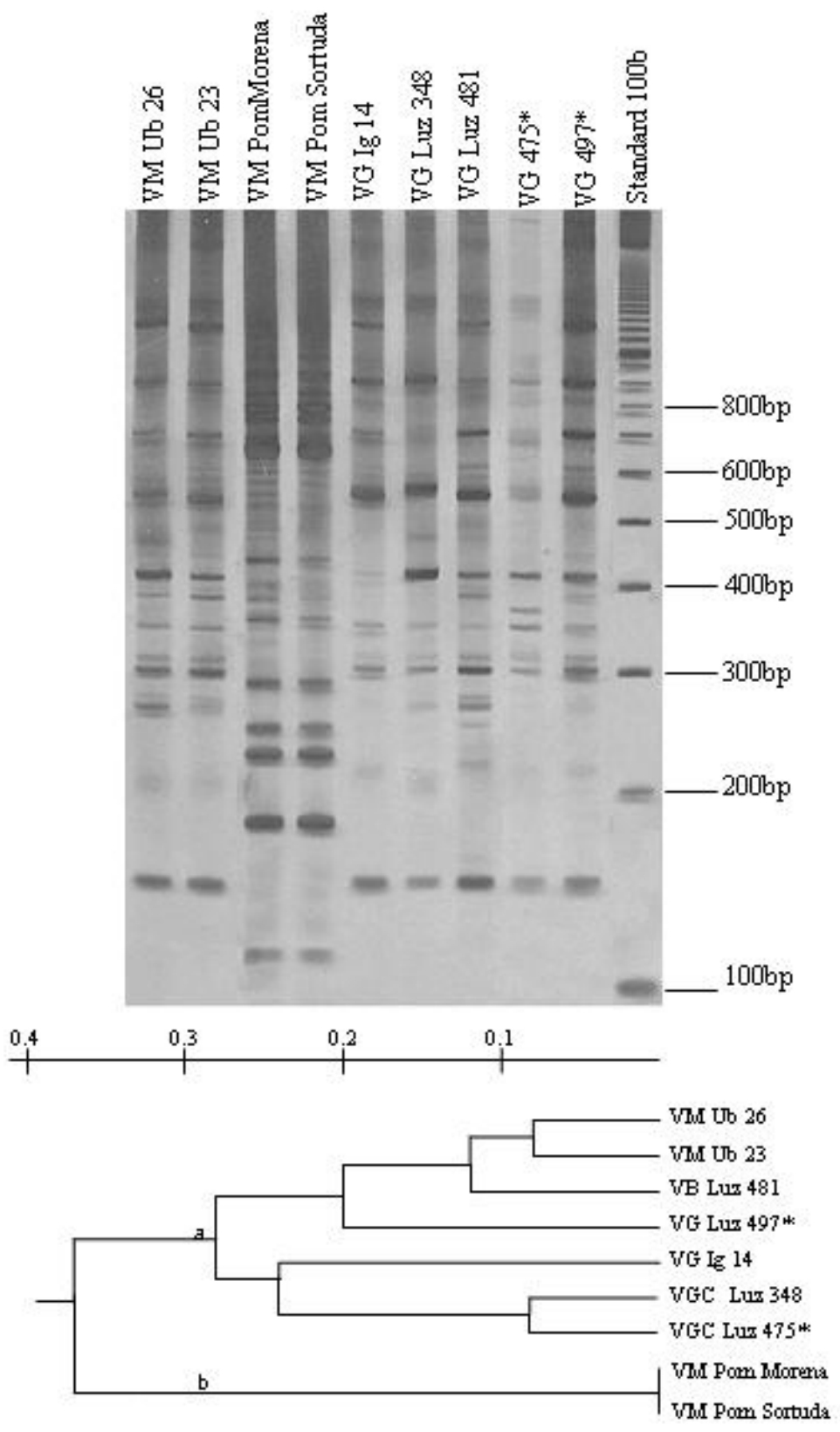

Figure 1. RAPD profile of genomic DNA with OPA 2 primer on $8 \%$ polyacrilamide gel and the phenogram constructed by UPGMA of M. sympodialis from cattle with or without otitis. *The strains Vg Luz 475, Vg Luz 497 were isolated from cattle with otitis. 
In figure 2, the eletrophorectic profiles and the phenograms of $M$. furfur with M13 primer is performed. Three genetic types could be observed and were clustered in three different groups $(a, b, c)$. Strains isolated from cattle with otitis were not observed in the group c.

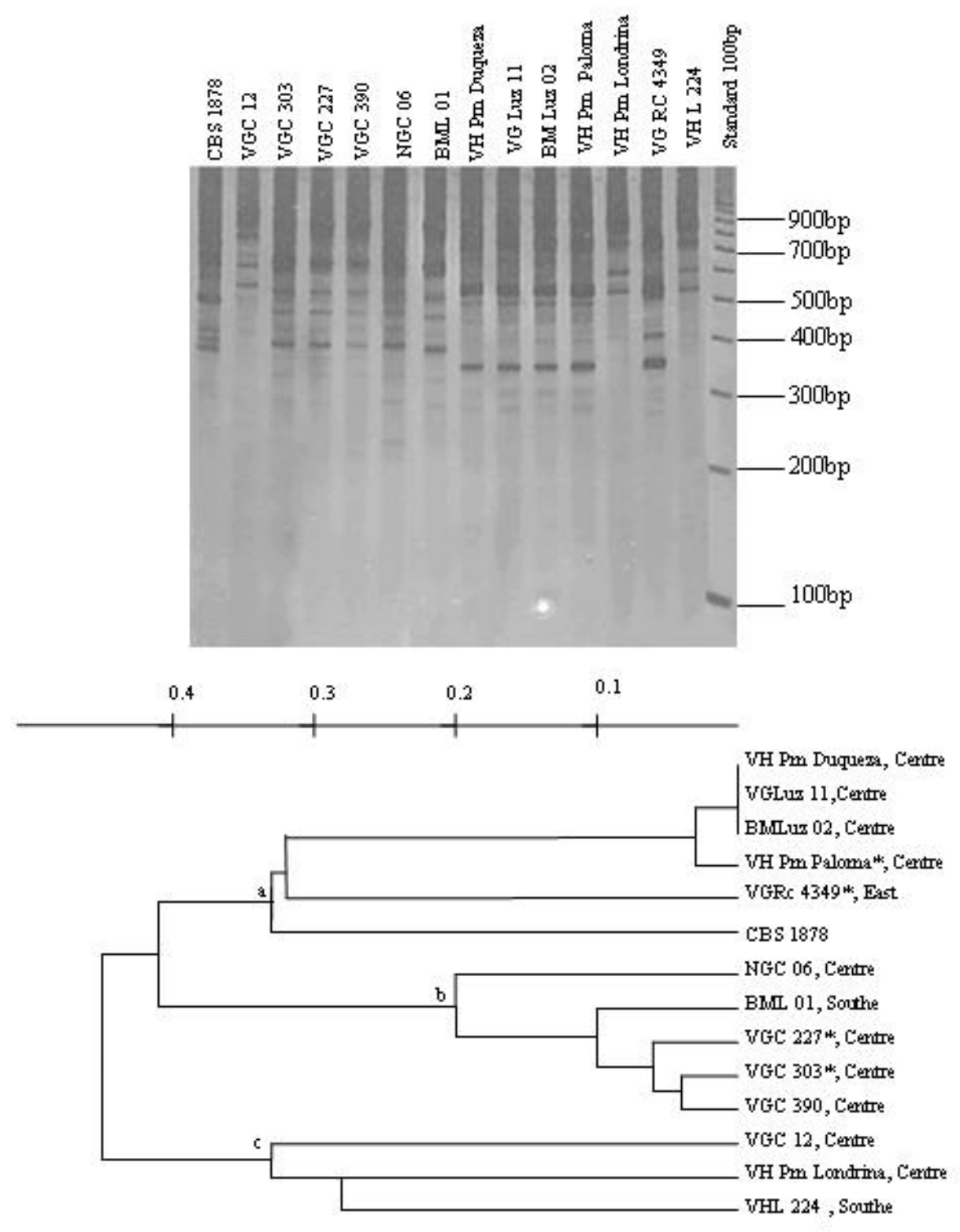

Figure 2. RAPD profile of genomic DNA of Malasseiza furfur with M13 primer analyzed by electrophoresis on $8 \%$ polyacrilamide gel and phenogram constructed by UPGMA.

*The strains VGC 227, VGC 303, VH Pm Paloma, and VGRc 4349 were isolated from cattle with otitis.

For the comparison of possible heterogeneity between strains from cattle with and without otitis, strains of same bovine herd were selected because, in preliminary a research, genetic heterogeneity between Malassezia strains isolated from different geographic regions had been observed. This heterogeneity in the DNA profile of Malassezia strains isolated from 
different origin could be detected for some strains isolated in this study and may be clarified in future studies (Figure 1 and 2).

The technique of RAPD, using the available primers, did not show the formation of genetically distinct groups between strains isolated from cattle with or without otitis from the same herd in phenograms constructed using the UPGMA.

These data could suggest that samples of these species with similar genomic characteristics are members of the same population and could be present in the ear of healthy cattle as members of the normal microbiota, or in cases of otitis active in the inflammatory process. It was not possible to show divergent bands between samples from healthy animals and those with otitis which could indicate the selection of specific genotypes involved in the pathological process.

The strains evaluated are members of the normal microbiota of the bovine ear. However, in the presence of trigger factors, these fungi may reveal their opportunistic character, participating in the etiopathology of bovine external otitis. Factors such as the intensity and the time of parasitic infestation, long, pendant and guttershaped external ears may alter the equilibrium in the population of yeasts of the genus Malassezia, favouring their growth (Duarte et al., 2003).

In a study of genetic diversity of $M$. pachydermatis strains isolated from dogs with external otitis or seborrheic dermatitis (SD), DNA profiles of 13 clinical samples and the reference sample $M$. pachydermatis (CBS 1879) were similar, showing 12 bands using the technique of RAPD (Aizawa et al., 1999). This species is an important member of normal microbiota of the external ears of dogs and did not demonstrate genetic heterogeneity. Other research studied the relationship between production of enzymes and pathogenicity of $M$. pachydermatis strains isolated from canine ear with and without otitis. No differences in the enzymatic activity among the isolated strains were observed (Coutinho, 2005).

In an analysis of molecular characteristics of human Malassezia strains, Theelen et al. (2001) reported that most of them isolated from patients with systemic diseases belonged to a similar intraspecific RAPD genotype. This suggested a strong systemic selection pressure resulting in a single genotype of the yeast in human systemic diseases of one hospital.

A total of $47 M$. furfur strains isolated from human subjects with pityriasis versicolor (PV), $\mathrm{SD}$ and SD of the HIV positive subjects were characterized by RAPD-PCR analyses. A distinct differentiation between strains isolated from PV and SD subjects with or without AIDS was observed. The results indicated that RAPD- PCR showed to be an efficient epidemiological tool to determine the origin of the isolated strains of $M$. furfur in different skin disease (Gandra et al., 2006). Similar results obtained from subjects with dermatosis or systemic infections were observed by Guého et al. (1998) and it was suggested that an intra-specific genetic variation determine the presence of the different populations of $M$. furfur.

The participation of the yeast of the normal microbiota of bovine ear in the pathological process is notable. This study showed similar DNA profiles between Malassezia strains from healthy cattle and cattle with otitis, raised in the same herd, using the RAPD analysis. However, strains isolated from cattle with otitis were not observed with one specific genetic type of $M$. furfur and it may be clarified with the analysis of other strains this species. The continuation of these researches with a great number of strains may elucidate the epidemiology and pathogenicity of Malassezia infections in cattle, other domestic animals, and in humans.

\section{ACKNOWLEDGEMENTS}

This research was supported by the Conselho Nacional de Desenvolvimento Científico e Tecnológico (CNPq), Fundação de Amparo à Pesquisa do Estado de Minas Gerais (FAPEMIG), and Coordenação de Aperfeiçoamento de Pessoal de Nível Superior (CAPES).

\section{REFERENCES}

AIZAWA, T.R.; KANO, Y.; NAKAMURA, S. et al. Molecular heterogeneity in clinical isolates of Malassezia pachyderamtis from dogs. Vet. Microbiol., v.70, p.67-75, 1999. 
ARAÚJO, R.S.; VIANNA, S.S.S.; PEREIRA J.R. Aspectos epidemiológicos de Raillietia auris (Leidy, 1872) Trouessart, 1902, (Mesostigmata : Raillietidae), no vale do Paraíba e região serrana, do estado de São Paulo, Brasil. Rev. Bras. Parasitol. Vet., v.5, p.33-36, 1996.

BELKUM, A.; BOUKHOUT, T.; BOSBOOM, R. Montoring spread of Malasseiza infections in a neonatal intensive care unity by PCR-mediated genetic typing. J. Clin. Microbiol., v.32, p.25282532, 1994

COUTINHO, S.D.A. Malassezia pachydermatis: enzymes production in isolates from external ear canal of dogs with and without otitis. Arq. Bras. Med. Vet. Zootec., v.57, p.149-153, 2005.

DUARTE, E.R.; BATISTA, R.D.; HAHN, R.C. et al. Factors associated with the prevalence Malassezia species in the external ears of cattle from the State of Minas Gerais, Brazil. Med. Mycol., v.41, p.137-142, 2003.

DUARTE, E.R.; MELO, M.M.; HAHN, R.C. et al. Prevalence of Malassezia spp. in the ears of asymptomatic cattle and cattle with otitis in Brazil. Med. Mycol., v.37, p.159-162. 1999.

DUARTE, E.R.; MELO, M.M.; HAMDAN, J.S. Epidemiolgical aspects of bovine parasitic otitis caused by Rhabditis spp. and/ or Raillietia spp. in the State of Minas Gerais, Brazil. Vet. Parasitol., v.101, p.45-52, 2001 a.

DUARTE, E.R.; RESENDE, J.C.; ROSA, C.A. et al. Prevalence of yeasts and mycelial fungi in bovine parasitic otitis in the State of Minas Gerais, Brazil. J. Vet. Med. B, v.48, p.631-35, 2001b.

GANDRA, R.F.; SIMÃO, R.C.G.; MATSUMOTO, F.E. et al. Genotyping by RAPD-PCR analyses of Malassezia furfur strains from pityriasis versicolor and seborrhoeic patients. Mycopathologia, v.162, p.273-280, 2006.

GUÉHO, E.; BOEKHOUT, T.; ASHBEE, H.R. et al. The role of Malassezia species in the ecology of human skin and as pathogens. Med. Mycol., v.36, p.220-229, 1998.

GUILlot, J.; CHERMETTE, R.; GUÉHO, E. Prevalénce du genre Malassezia chez les mammifères. J. Med. Mycol., v.4, p.72-79, 1994.

LEITE, C.A.L.; ABREU, V.L.V.; COSTA, G.M. Freqüência de Malassezia pachydermatis em otite externa de cães. Arq. Bras. Med. Vet. Zootec., v.55, p.102-104, 2003.

MAYSER, P.; WILE G.; IMKAMPE, A. Synthesis of flurochromes and pigments in Malassezia furfur by use tryptophane as single nitrogen source. Mycoses, v.39, p.225-231, 1998.

OLIVEIRA, L.C.; BRILHANTE, R.S.N.; CUNHA, A.M.S. et al. Perfil de isolamento microbiano em cães com otite média e externa associados. Arq. Bras. Med. Vet. Zootec., v.59, p.1009-1017, 2007.

SANTOS, F.R.; PENA, S.D.; EPPLEN, J.T. Genetic a population study of a y-linked tetranucleotide repeat DNA polymorphism with a simple non-isotopic technique. Human Genet., v.90, p.655-656, 1993.

SAMBROOK, J.; FRITSCH, E.F.; MANIATIS, T. (Eds). Molecular cloning: a laboratory manual. 2.ed. New York: Cold Spring Harbor Laboratory 1989. 411p.

THEELEN, B.; SILVESTRI, M.; GUÉHO, E. Identification and typing of Malassezia yeasts using amplified fragment length polymorphism (AFLP Tm), random amplified polymorphic DNA (RAPD) and denaturing gradient gel electrophoresis (DGGE). FEMS Yeast Res., v.1, p.79-86, 2001.

VAN DE PEER, Y.; WACHTER, R. TREECON for Windows: a software package for the construction and drawing of evolutionary trees in the Microsoft Windows environment. Comp. Appl. Biosci., v.10, 569-70, 1994. 